\title{
TRIBUTE TO A LAW TEACHER WITH A HEART AND A SOCIAL CONSCIENCE
}

\author{
Sir Geoffrey Palmer $Q C^{*}$
}

It has been my privilege and pleasure to know Professor Bill Atkin since he joined the Faculty of Law at Victoria University of Wellington in 1975. I was then a recently appointed Professor at Victoria, fresh from Australia and the United States. Bill had been at the University of Bristol after graduating from the Victoria. He took over the family law course from Professor Don Inglis who had given up teaching for full-time law practice. (Inglis himself was a law teacher of great renown who pioneered scholarship on family law in New Zealand and he became in due course a Family Court Judge). I was teaching torts and constitutional law in those days. When I left Victoria to go into politics in 1979, Bill took over torts.

It was my pleasure in politics to encounter Bill's father Roy, who was then a key person in the Office of the Clerk of the House of Representatives. He supplied the MPs with bills and other documents they needed before they could debate or attend select committee hearings. Bill's father also officiated as umpire at the annual Parliamentarians v the Diplomats cricket match. He gave me out LBW on one occasion.

Bill has made a heavy scholarly contribution in two fields, family law and the law of torts. He has a formidable list of insightful publications. While he has also been published extensively overseas, Bill has never forgotten that it is the duty of a New Zealand academic to make a contribution to the development of New Zealand law.

Family law has changed in my professional lifetime more than any other area of law, or so it seems to me. When I started practising law 50 years ago, I was often in the Magistrate's Court dealing with the securing of separation and maintenance orders for women under a piece of legislation called the Destitute Persons Act 1910. The title says it all. The grounds for relief were based firmly on matrimonial fault. It was necessary to prove one of the following grounds: failure to provide adequate maintenance; persistent cruelty; that the defendant was an habitual inebriant; or proof that the defendant had been convicted within the prior six months of assault or other offence

* Barrister, Distinguished Fellow Faculty of Law and Centre for Public Law, Victoria University of Wellington. 
of violence against the complainant. ${ }^{1}$ In the mid-1960s the grounds had not been changed since the legislation was enacted in 1910.

That legislation was not so much Edwardian as Victorian. How it could have survived for so long remains a mystery to me. Frightened women were cross-examined within an inch of their lives. This was full blown adversarial litigation without a hint of any therapeutic approach: no counselling, no mediation. I remember a woman for whom I was acting, who lived in Porirua, telephoning me at home at night saying: "He threw a cup of tea at me Mr Palmer, what shall I do?" There was little that I could do. The police steered well clear of domestic disputes in those days. Compared to today, the legal landscape when Bill started teaching family law is unrecognisable. The changes have been massive.

I sat on the Select Committee that scrutinised the Bill that became the Family Courts Act $1980 .^{2}$ I thought and still think this bold innovation was humane, effective and progressive, and a good piece of legislation. The law in the family area has developed to provide more equal justice on the basis of gender, especially in the division of matrimonial property at the time of divorce. The legal methodology these days centres on people, and solving their problems not punishing them. While it does not yet amount to what is called therapeutic jurisprudence it is heading in that direction. However, the latest set of changes to the Family Courts seems to me to be misconceived. The desire to cut costs that drove the way in which the recent reforms were designed is sure to create extra social costs elsewhere. From a societal point of view, it is just not worth it.

While New Zealand family law has not lacked innovation, it still exhibits incoherence. Bill Atkin said in his inaugural lecture in 2006, "when we unpack the law we discover a legal and policy jumble". ${ }^{3}$ It has not got any better since then. There remain many areas of difficulty that need to be addressed by the legislature; family violence and sexual abuse being high on the agenda. There are some other minor scandals in our family law as well. Years of refusal to introduce legislation to reform the Adoption Act 1955 has meant that the legislation is so far out of date with modern conceptions that it is just not fit for purpose.

Bill Atkin has been not only a successful and influential scholar but also a wonderful teacher. He engenders within the students a sense of enthusiasm and curiosity. He achieves this not by raising his voice or becoming belligerent. He does it by creating a sense of collegiality and compassion. He imbues students with those values. It is hardly surprising that the students love him. He has trained a great many family lawyers over the years in New Zealand and helped mightily to make the family law bar in New Zealand progressive and constructive.

1 Destitute Persons Act 1910, s 17(1).

2 Family Courts Bill 1979 (143).

3 Quoted in "Family Law 'a Legal and Policy Jumble'" (2006) 264 Law Talk 16. 
Bill has been a faithful servant of the Victoria Law Faculty for more than 40 years. He has taken a full part in shouldering more than his share of the administrative load. I have had dealings with him over the years, most recently over the Victoria University of Wellington Law Review, and his stewardship of that fine journal has been of a high standard.

Bill Atkin is the sort of academic that a dean can rely on - rely on to carry the load; to fill the breach when something goes wrong; to help the students; to get things done on time; to encourage the students to apply for scholarships overseas; and generally to be an exemplary faculty citizen. What more can one ask of a conscientious law teacher? Bill Atkin is an outstanding academic lawyer who has made a significant contribution to the improvement of the law in New Zealand. He does not advertise himself. He does not seek the limelight. He does his work in an inconspicuous but effective manner and he has shone light into many areas of legal darkness.

Family law lies at the foundation of human society. It says a lot about what sort of society we are. We are a better society in human terms now than when the Destitute Persons Act 1910 held sway. Bill, I salute you. 
